O.O. Palchykov

\title{
BREAKDOWN VOLTAGE OF MICRON RANGE AIR INCLUSIONS IN CAPACITOR PAPER
}

Purpose. To substantiate the breakdown mechanism of capacitor paper on the basis of numerical-field models with segmented cross-sections of cylindrical volumes of air and water, and also use the proposed models to determine the breakdown strength of air in micron-sized gaps under normal conditions. Methodology. The model bases on a finite element solution to an electrostatic problem in a volume of capacitor paper consisting of cellulose and pores with air and water. First, the possible scenarios for the growth of breakdown in capacitor paper are analyzed and to the conclusion is made, that complete breakdown developed from a partial breakdown in the air cavity. A brand of capacitor paper is chosen in such a way that when its thickness changed, the breakdown strength of the electric field changed over a wide range. Then, for the paper with the lowest average electric field intensity the possibility of explaining the complete breakdown by the breakdown of air segments on the basis of the Paschen dependence is checked. Further points of the obtained dependence by constructing models of papers of the same brand and a different thickness under the assumption of the similarity of electrostatic fields are determined. As such a criterion, the constancy of the equivalent effective permittivity are taken. Results. The dependence of the breakdown strength of the air in the range of 1.36...5.54 $\mu \mathrm{m}$ under normal conditions is determined. The obtained relationship is between the Peschot and Taev curves. Originality. For the first time, the possibility of indirectly estimation the breakdown strength of an insulating material using an electrostatic field model is indicated. Practical value. The proposed method for the numerical calculation of the breakdown voltage of air inclusions in the presence of water inclusions in the thickness of solid insulation can be applied to other types of solid thin-layer insulation. References 11 , tables 3 , figures 5.

Key words: electrical breakdown, model of capacitor paper, micron gap, electrostatic field, finite element method.

Отримана в роботі залежність напруженості електричного поля повітря від довжини розрядного проміжку задовільно пояснюе значення пробивних напруг зразків конденсаторного паперу при зміні їх марок $і$ товщини. Побудована залежність пробивної напружсності повітря при нормальних умовах в діапазоні 1,36...5,54 мкм на підставі розрахунку електростатичних полів в моделях конденсаторного паперу з сегментними поперечними перетинами циліндричних об'ємів повітря $і$ води. Проведено зіставлення отриманої залежності 3 відомими експериментальними даними. Отримані дані в діапазоні 2...5,54 мкм найбільш близькі експериментальним даним Пешо. Бібл. 11, табл. 3, рис. 5.

Ключові слова: електричний пробій, модель конденсаторного паперу, мікронний проміжок, електростатичне поле, метод скінченних елементів.

Полученная в работе зависимость напряженности электрического поля воздуха от длины разрядного промежутка удовлетворительно объясняет значения пробивных напряжений образцов конденсаторной бумаги при изменении их марок и толщины. Построена зависимость пробивной напряженности воздуха при нормальных условиях в диапазоне 1,36...5,54 мкм на основании расчета электростатических полей в моделях конденсаторной бумаги с сегментными поперечными сечениями цилиндрических объемов воздуха и воды. Проведено сопоставление полученной зависимости с известными экспериментальными данными. Полученные данные в диапазоне 2...5,54 мкм наиболее близки экспериментальным данным Пешо. Библ. 11, табл. 3, рис. 5.

Ключевые слова: электрический пробой, модель конденсаторной бумаги, микронный промежуток, электростатическое поле, метод конечных элементов.

Introduction. If the technological mode of impregnation is violated (insufficient pressure during impregnation), air inclusions remain in the thickness of the capacitor paper, in which discharges occur during operation under high voltage. Therefore, it becomes necessary to evaluate the breakdown voltage of air inclusions of capacitor paper.

In this paper, it is proposed to determine the breakdown voltage of the power frequency of air in the micron range based on indirect estimates of the calculated values made on the basis of numerical modelling of the electrostatic field in capacitor paper with air inclusions. Capacitor paper is a three-component dielectric made up of cellulose, air and water. The choice of such a dielectric is based on the assumption that a change in the breakdown voltage with a change in thickness is explained by the development of a complete dielectric breakdown from a partial one in the air region. When the test voltage is applied, the electric field is distributed irregularly according to the dielectric permittivity and the arrangement of the components. For example, for the considered insulating material in water, the modulus of the electric field strength (EFS) is the smallest, and in air it is the largest. Then, the possibility of a breakdown is checked for a section with an almost uniform EFS vector both in absolute value and in direction. If the check is satisfied, then this area is replaced with a perfectly conductive one. And everything is repeated until the discharge spreads over the entire thickness of the dielectric.

Literature review. In 1889 Friedrich Paschen established that the breakdown voltage in gases depends on the product of the gas pressure and the distance between the electrodes. Further studies have shown deviations from this law of similarity of gas discharges. Reviews of experimental studies of air breakdown at normal atmospheric pressure and micron gaps are given in [1-3], and the latest data in [4]. As a result, it was found that at normal pressure the left branch of the Paschen

(C) O.O. Palchykov 
dependence falls with a decrease in the product of pressure and the distance between the electrodes, and the dependence of the breakdown voltage on the material of the electrodes is also determined. However, the experimental data of various authors differ greatly and sometimes even contradict each other.

It was also found that for air the breakdown voltage does not depend on the frequency at $f=0 . .50 \mathrm{~Hz}$ in discharge gaps up to $600 \mathrm{~cm}$. For water and solid dielectrics, an increase in dielectric strength is observed at voltage exposure time commensurate with the germination time of the discharge channel (for liquids $0.01 \mu \mathrm{s}$ at a thickness of $10 \ldots 100 \mu \mathrm{m}$, for solid dielectrics $-0.1 \mu \mathrm{s}$ at a thickness of $1 \mathrm{~mm}$ ) [5].

The influence of air cavities on the development of a discharge in a polymer, taking into account the distribution of the electrostatic field and mechanical stresses, was analyzed in [6]; however, the Paschen dependence is taken as the breakdown condition.

The goal of the work is the determination of the breakdown voltage of micron range air inclusions in capacitor paper on the basis of numerical-field models of the electric field with segmental cross-sections of cylindrical volumes of air and water in cellulose.

A mathematical model. The volume ratio of the components of the capacitor paper is determined based on the equations:

$$
\left\{\begin{array}{l}
V_{\mathrm{p}} \rho_{\mathrm{p}}(1-y)=V_{\mathrm{c}} \rho_{\mathrm{c}}+V_{\mathrm{a}} \rho_{\mathrm{a}} \\
V_{\mathrm{w}} \rho_{\mathrm{w}}=V_{\mathrm{p}} \rho_{\mathrm{p}} y \\
V_{\mathrm{p}}=V_{\mathrm{c}}+V_{\mathrm{a}}+V_{\mathrm{w}}
\end{array}\right.
$$

where $V_{\mathrm{p}}, V_{\mathrm{c}}, V_{\mathrm{a}}$ and $V_{\mathrm{w}}$ are the volumes of paper, cellulose, air and water, respectively; $\rho_{\mathrm{p}}, \rho_{\mathrm{c}}, \rho_{\mathrm{a}}$ and $\rho_{\mathrm{w}}$ are the densities of paper, cellulose, air and water, respectively; $y$ is the relative mass content of water in insulating paper.

Then the radius of pores containing air and water, of the length $l$ and the amount $N$ in the cellulose volume is

$$
r=\left[\left(V_{\mathrm{a}}+V_{\mathrm{w}}\right) /(\pi \cdot l \cdot N)\right]^{0,5} \text {. }
$$

An example of the location of the volumes of air and water in a pore is shown in Fig. 1. The cross-sections of the cylindrical volumes of pore materials are divided by the central curved trapezoids into three regions. The bases of such trapeziums occupy $20 \%$ of the length of the line of separation of air and water media. This was done in order to distinguish subregions with practically uniform EFS in the air and water regions.

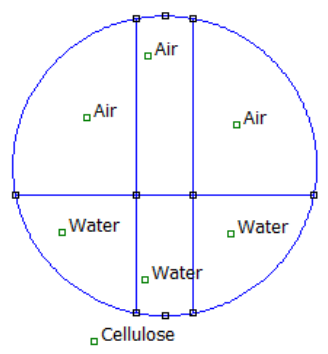

Fig. 1. Fragment of the calculation area

The calculation of the electric field in the crosssection with respect to the length $l$ of the capacitor paper with the width $b$ and the thickness $h$ is based on the following differential equations [7], compiled for each isotropic region with relative dielectric permittivity $\varepsilon$ :

$$
\left\{\begin{array}{l}
\nabla^{2} \varphi=0 \\
\boldsymbol{E}=-\nabla \varphi \\
\boldsymbol{D}=\varepsilon_{0} \varepsilon \boldsymbol{E},
\end{array}\right.
$$

where $\varphi$ is the electrostatic scalar potential; $\boldsymbol{E}$ is the EFS vector; $\boldsymbol{D}$ is the electric induction vector; $\varepsilon_{0}$ is the electrical constant, $\varepsilon_{0}=8.854 \cdot 10^{-12} \mathrm{~F} / \mathrm{m}$.

At the interface between the two media, the condition of constancy of the electrostatic scalar potential and the condition of equality of the normal components of the vectors of the electric induction of these media are satisfied, which takes the following form for two dielectrics or a dielectric and a conductor, respectively [7]:

$$
\varepsilon_{1} \frac{\partial \varphi_{1}}{\partial \boldsymbol{n}_{12}}-\varepsilon_{2} \frac{\partial \varphi_{2}}{\partial \boldsymbol{n}_{12}}=0 ; \quad \varepsilon_{1} \frac{\partial \varphi_{1}}{\partial \boldsymbol{n}_{12}}=\sigma,
$$

where $\varepsilon_{1}$ and $\varepsilon_{2}$ are the relative dielectric permittivities of the first and second media, respectively; $\boldsymbol{n}_{12}$ is the normal from the first to the second medium; $\sigma$ is the surface charge at the interface between two media.

On the upper and lower planes perpendicular to the thickness of the considered volume, scalar electrostatic potentials are set equal in magnitude to half of the amplitude of the breakdown voltage of the capacitor paper indicated in [8], but with different signs. The solution area is limited by a cylindrical surface with radius of $200 \mu \mathrm{m}$, length of $100 \mu \mathrm{m}$ and a zero potential on its surface.

To implement the connection between the value of the breakdown EFS of the material and its geometry, the area occupied by the material is divided into a number of subregions of a rectangular or curvilinear trapezoidal shape so that the vectors of the EFS of their individual elements are parallel to the direction vectors of the two sides of the subregions (hereinafter called lateral) with a given accuracy, and the values of the moduli of the EFS vectors changed insignificantly. Further, the EFS vector is averaged over the area of the subregion $S$ :

$$
\boldsymbol{E}_{\mathrm{A}}=\frac{1}{S} \int_{S} \boldsymbol{E} d S .
$$

Then the modulus of the resulting vector will be equal to its normal component defined for the base of the subregion. Consequently, with this approach, the modulus of the EFS vector determines the onset of breakdown in the discharge gap equal to the length of the side $L$ of the subregion under consideration.

The basic assumptions of the model: dielectric materials do not possess conductivity; there are no charges at their interfaces; there are no space charges in dielectric materials, and their volumes do not change under the influence of an electrostatic field; ideal conductors with infinitesimal thickness are sources of an electrostatic field; the time of breakdown development in the volume of the samples under study is less than $1 \mu \mathrm{s}$.

Numerical calculation of the electrostatic field by the finite element method is implemented in the FEMM computer code. 
The theory of point defects can explain an increase in the breakdown voltage of paper with a decrease in thickness and an increase in density due to the fact that structural defects of the cellulose itself decrease [9]. An alternative explanation can be the well-known effect of increasing the breakdown voltage of thin samples of onecomponent insulating materials. In our case, the hypothesis is that with a decrease in the thickness of the capacitor paper, the areas occupied by cellulose also decrease, and their breakdown voltage will correspondingly increase. Consider samples of capacitor paper of various brands and the same thickness given in Table 1 [8]. If, in this case, the air volumes do not determine the breakdown voltage of the insulating material, then it turns out that the breakdown voltage should be higher for papers with a lower average density than for papers with a higher density, since their areas occupied by cellulose will be smaller. However, this is contrary to experience. Consequently, this hypothesis about the explanation of the change in the breakdown voltage of a series of capacitor paper of different thickness cannot be consistent. The influence of water volumes on the resulting breakdown voltage of the sample is insignificant, as shown by modelling. This is due to an insignificant voltage drop in the specified region, and upon its breakdown, the distribution of the electrostatic field in the paper will change negligibly little.

Table 1

\begin{tabular}{|c|c|}
\hline \multicolumn{2}{|c|}{ Breakdown voltage of capacitor paper } \\
\hline Paper brand & $\begin{array}{c}\text { Breakdown voltage amplitude } \\
U, \mathrm{~V}\end{array}$ \\
\hline $\begin{array}{c}\text { MKOH 0,8- } \\
10\end{array}$ & 495 \\
\hline CKOH 1-10 & 594 \\
\hline KOH 2-10 & 537 \\
\hline KOH 3-10 & 594 \\
\hline
\end{tabular}

In the reference literature for cellulose, the values of the breakdown EFS are in the range of $120 \ldots 320 \mathrm{MV} / \mathrm{m}$ [10]. The dependence of the breakdown EFS of water on the length of the discharge gap is shown in Fig. 2. The points were obtained in [11] at a pulse voltage with amplitude of $800 \mathrm{~V}$ and front steepness of $0.5 \mu \mathrm{s}$. It is proposed to approximate the law shown in Fig. 2 by the dependence

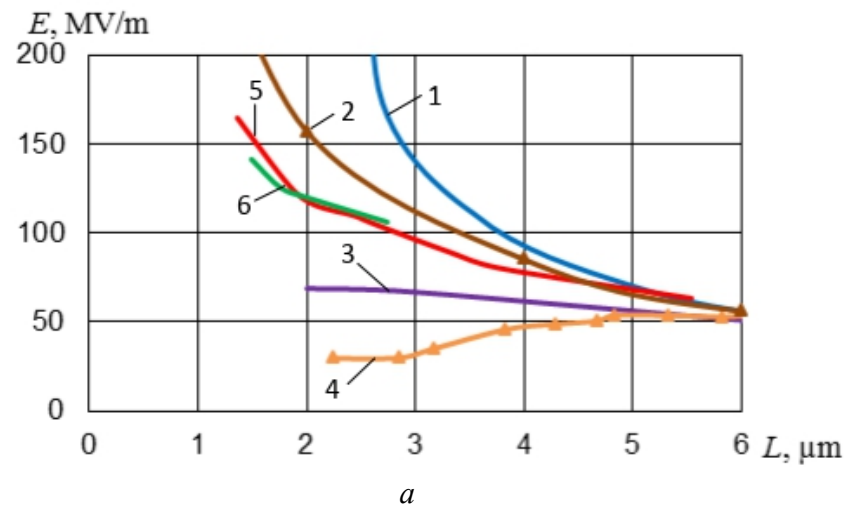

$E_{\mathrm{w}}=6,9-0,017 \cdot L$.

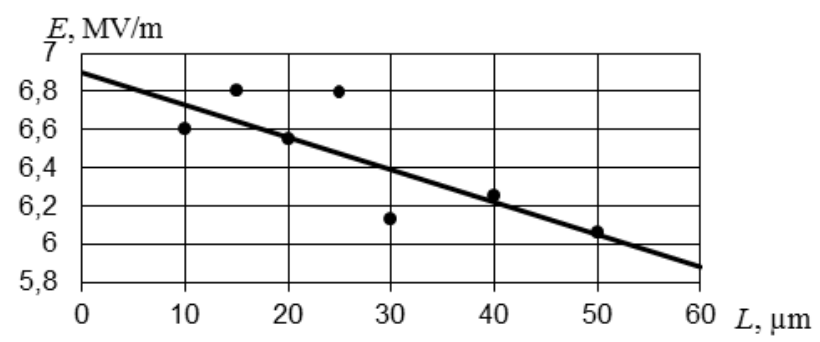

Fig. 2. Dependence of the breakdown strength of the electric field of the water gap on its length

The unambiguity of determining the breakdown ES of air is provided by information on the pore size, but such information is absent in [8]. Therefore, to explain the difference in the breakdown voltage of capacitor paper brands with a change in their thickness, a hypothesis was proposed that the electric fields in the samples under consideration are similar, and their quantitative characteristics - the potential and strength frm point to point differ only by the proportionality coefficient. That is, for capacitor paper samples of different thicknesses, the equivalent dielectric permittivity must be constant.

Strongly ionized regions arising during partial or complete breakdown were modelled by a material with relative dielectric permittivity $\varepsilon=16000$. This value was chosen for the practical implementation of the model of an ideal conductor with $\varepsilon \rightarrow \infty$, which is several times higher than the value of the maximum dielectric permittivity of the model materials. The rest of the physical parameters used in the model are given in Table 2.

Table 2

Physical properties of dielectric materials

\begin{tabular}{|l|c|c|}
\hline Name & $\begin{array}{c}\text { Density at } 20^{\circ} \mathrm{C}, \\
\mathrm{kg} / \mathrm{m}^{3}\end{array}$ & $\varepsilon_{20}$ \\
\hline Cellulose & 1530 & 6,5 \\
\hline Air & 1,205 & 1,00058 \\
\hline Water & 998 & 80,2 \\
\hline
\end{tabular}

Research results. The dependencies of the breakdown EFS and voltage for air, obtained on the basis of the proposed model for a series of capacitor paper of the $\mathrm{KOH} 2$ brand of various thicknesses, are shown in Fig. 3, and additional information is presented in Table 3.

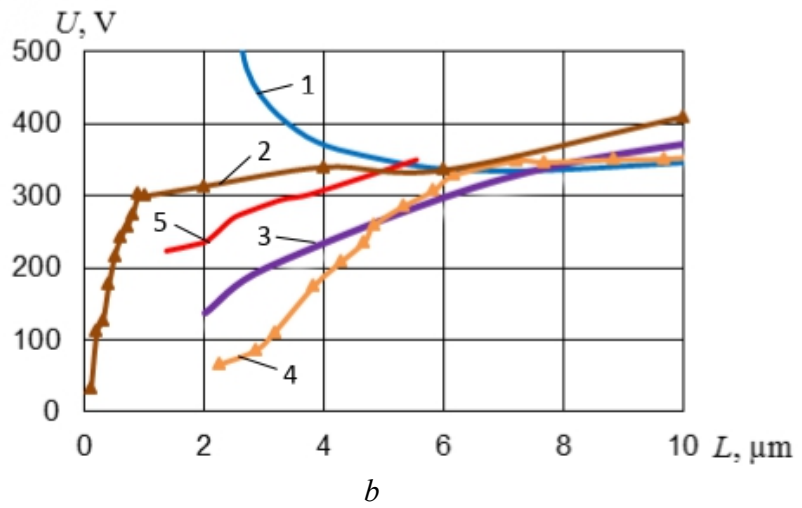

Fig. 3. Dependences of the breakdown strength $(a)$ and breakdown voltage $(b)$ of the air gap on its length, determined from the curves of Paschen (1), Peschot (2), Taev (3), Slade (4), and calculated according to the proposed model for a series of papers $\mathrm{KOH} 2$ (5), KOH 3 (6) 
Model parameters of capacitor paper $\mathrm{KOH} 2$

\begin{tabular}{|c|c|c|c|c|c|c|c|c|}
\hline \multirow[b]{2}{*}{ Paper brand } & \multirow{2}{*}{$\begin{array}{l}\text { Dimensions } \\
h \times b \times l, \mu \mathrm{m}\end{array}$} & \multirow{2}{*}{$\begin{array}{c}\text { Voltage } \\
\text { amplitude } U, \\
\text { V }\end{array}$} & \multirow{2}{*}{$\begin{array}{c}\text { Number of } \\
\text { pores } N\end{array}$} & \multirow{2}{*}{$\begin{array}{c}\text { Air } \\
\text { subregion } \\
\text { length } L_{\mathrm{a}}, \\
\mu \mathrm{m}\end{array}$} & \multirow{2}{*}{$\begin{array}{c}\text { Water } \\
\text { subregion } \\
\text { length } L_{\mathrm{w}}, \\
\mu \mathrm{m}\end{array}$} & \multirow{2}{*}{$\begin{array}{c}\text { Relative } \\
\text { equivalent } \\
\text { dielectric } \\
\text { permittivity } \varepsilon\end{array}$} & \multicolumn{2}{|c|}{$\begin{array}{l}\text { Water electric field strength } \\
\text { module } E_{\mathrm{w}} \cdot 10^{-6}, \mathrm{~V} / \mathrm{m}\end{array}$} \\
\hline & & & & & & & $\begin{array}{l}\text { maximum by } \\
\text { model }\end{array}$ & $\begin{array}{c}\text { by } \\
\text { dependence } \\
\text { (1) }\end{array}$ \\
\hline KOH 2-30 & $30 \times 190,08 \times 100$ & 975,80 & 24 & 5,54 & 3,76 & 5,241 & 2,41 & 6,836 \\
\hline KOH 2-18 & $18 \times 202,36 \times 100$ & 721,24 & 33 & 3,78 & 2,56 & 5,241 & 3,44 & 6,856 \\
\hline $\mathrm{KOH} \mathrm{2-15}$ & $15 \times 184,72 \times 100$ & 664,68 & 33 & 3,31 & 2,23 & 5,234 & 3,73 & 6,862 \\
\hline $\mathrm{KOH} 2-12$ & $12 \times 165,44 \times 100$ & 622,26 & 37 & 2,63 & 1,79 & 5,217 & 4,30 & 6,870 \\
\hline KOH 2-10 & $10 \times 150,84 \times 100$ & 537,40 & 33 & 2,43 & 1,65 & 5,217 & 4,40 & 6,872 \\
\hline $\mathrm{KOH} \mathrm{2-8}$ & $8 \times 134,92 \times 100$ & 494,98 & 33 & 2,07 & 1,39 & 5,238 & 4,34 & 6,876 \\
\hline $\mathrm{KOH} 2-6$ & $6 \times 116,80 \times 100$ & 395,98 & 27 & 1,84 & 1,24 & 5,264 & 5,34 & 6,879 \\
\hline $\mathrm{KOH} \mathrm{2-4}$ & $4 \times 95,40 \times 100$ & 339,42 & 27 & 1,36 & 0,92 & 5,232 & 6,60 & 6,884 \\
\hline
\end{tabular}

Figure 3 also shows the dependencies obtained on the basis of the experimental Paschen curve [5] recalculated to normal atmospheric pressure, the Taev curve for electrodes made of a metal composition of silver and cadmium oxide [1], the Slade curve [2] and the Peschot curve determined in the high precision electrode positioning system with a breakdown criterion of $50 \mathrm{nA}$ [4]. The construction of dependencies based on the numerical calculation of the electrostatic field began with the creation of a paper $\mathrm{KOH}$ 2-30 model. The value of the lateral side of the curvilinear trapezoid in the air segment of this model corresponds to the discharge gap of the Paschen curve with EFS equal to the modulus of the EFS vector averaged over the area of the indicated trapezoid. It should be noted that the distribution of the EFS in different air sectors is not the same. Therefore, the maximum value of the modulus of the averaged ES vector is taken as the breakdown one among the subregions located in the central part of the sample under consideration. Then, the equivalent dielectric permittivity was calculated using the energy method similar to [7]. The geometry of the next model of paper was selected so that its equivalent dielectric permittivity (within the error) was equal to the initial one determined for $\mathrm{KOH} 2-30$.

Based on the values of the lateral side of the curved trapezoid and the maximum modulus of the averaged EFS vector among all air segments in the central region of the sample, all subsequent points of the proposed dependencies were plotted. The obtained dependencies were verified by matching these curves and the known experimental point with coordinates $70 \mathrm{MV} / \mathrm{m}$ and $5 \mu \mathrm{m}$. The correctness of the obtained data is confirmed by the values of the moduli of the averaged EFS vectors over the areas of curvilinear trapezoids in the water segments of the pores of each model, which are less than the breakdown voltages for these gaps, determined by (1). However, after the breakdown of the air segment in water, the required value of the breakdown EFS is reached.

To confirm the obtained dependencies, a dependence was constructed in a similar way based on a series of capacitor paper of the $\mathrm{KOH} 3$ brand of various thicknesses, shown in Fig. 3,a. The discrepancy between the values obtained for this section does not exceed $9 \%$.

On the basis of the proposed model, the minimum EFS value was determined at which a breakdown begins

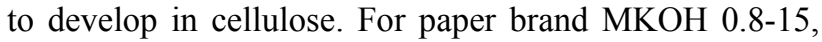
the radius and the number of pores were calculated in accordance with the proposed EFS curve. A fragment of the region of the sample under study is shown in Fig. 4. For the subregion of cellulose with a lateral side of 0.34 $\mu \mathrm{m}$, the EFS modulus was $141.5 \mathrm{MV} / \mathrm{m}$, which is within the above range of values.

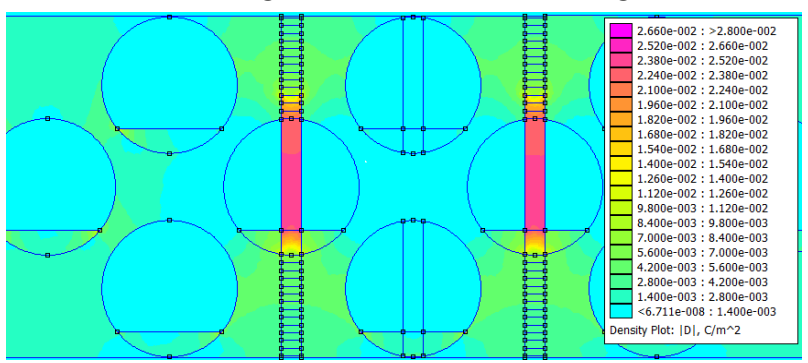

Fig. 4. Fragment of the distribution of the electrostatic field in MKOH 08-15 at partial breakdown
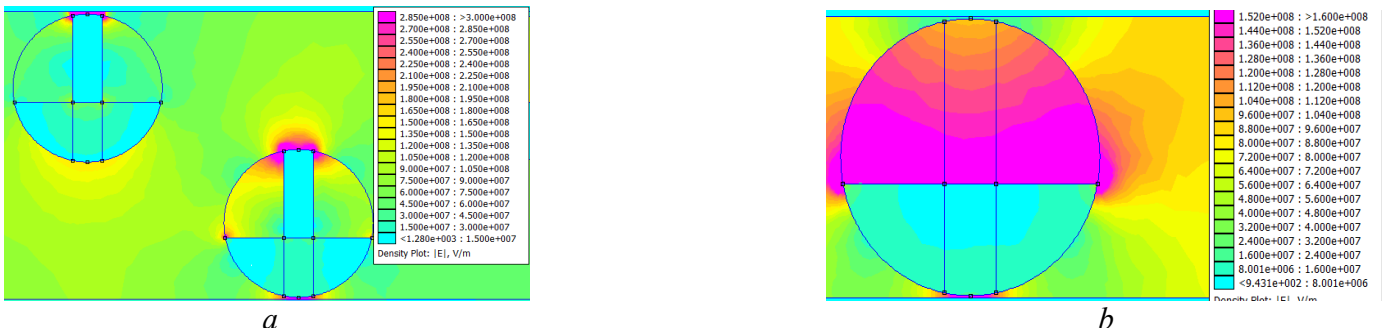

Fig. 5. Distribution of the electrostatic field during the development of breakdown according to Taev scenario for paper KOH 2-6 (a) and according to the Peschot scenario for paper $\mathrm{KOH} 2-4(b)$ 
The possibility of using the Taev curve to explain the breakdown mechanism of capacitor paper was verified using the example of a $1.84 \mu \mathrm{m}$ discharge gap. The corresponding distribution of the electrostatic field is shown in Fig. 5,a. In this case, the breakdown EFS of cellulose is 1.6 times exceeded, which leads to the identity of the breakdown voltage for papers of different thicknesses. When using the Peschot curve, the question of the mechanical shear strength of paper $\mathrm{KOH} 2$ samples with a thickness of $4 \ldots 6 \mu$ s arises It is also impossible to explain the value of the breakdown voltage of $\mathrm{KOH} 2-4$. As seen from Fig. 5, $b$, the pore diameter is practically equal to the thickness of the paper $\mathrm{KOH} 2-4$ sample, and the average EFS is $5.6 \%$ less than the predicted value of the Peschot curve. In the range of $2.09 \ldots 3.28 \mu \mathrm{m}$, the values of the EFS of the Peschot curve should be less by $1.6 \ldots 7.1 \%$ to explain the regularity of the breakdown voltage of the capacitor paper.

Conclusions. The dependence of the electric field strength of the air on the length of the discharge gap obtained in the work satisfactorily explains the values of the breakdown voltages of the samples of capacitor paper with a change in their brands and thickness. The best agreement of the obtained data is observed with the experimental Peschot dependence. The maximum divergence of the curves was $32 \%$ in the range of discharge gaps $2.00 \ldots 5.54 \mu \mathrm{m}$. The proposed method for numerical calculation of the breakdown voltage of air inclusions in the presence of water inclusions in the thickness of solid insulation can be applied to other types of solid thin-layer insulation.

\section{REFERENCES}

1. Gitlevich A.E., Mikhailov V.V., Parkanskii N.Ia., Revutskii V.M. Elektroiskrovoe legirovanie metallicheskikh poverkhnostei [Electrospark alloying of metal surfaces]. Kishinev, Shtiintsa Publ., 1985. 198 p. (Rus).

2. Fu Y., Zhang P., Verboncoeur J.P., Wang X. Electrical breakdown from macro to micro/nano scales: a tutorial and a review of the state of the art. Plasma Research Express, Feb. 2020, vol. 2, no. 1, p. 013001. doi: 10.1088/2516-1067/ab6c84.
3. Babrauskas V. Arc breakdown in air over very small gap distances. Conference: Interflam 2013, vol. 2, pp. 1489-1498.

4. Peschot A., Bonifaci N., Lesaint O., Valadares C., Poulain C. Deviations from the Paschen's law at short gap distances from $100 \mathrm{~nm}$ to $10 \mu \mathrm{m}$ in air and nitrogen. Applied Physics Letters, 2014, vol. 105, iss. 12, p. 123109. doi: 10.1063/1.4895630.

5. Bortnik I.M., Beloglovskii A.A., Vereshchagin I.P., Vershinin Iu.N. Elektrofizicheskie osnovy tekhniki vysokikh napriazhenii [Electrophysical basics of high voltage engineering]. Moscow, MEI Publ., 2016. 704 p. (Rus).

6. El-Zein A., El Bahy M. M., Talaat M. A prediction methodology of electrical tree propagation in solid dielectrics. Journal of Electrical Engineering, 2009, vol. 9 (2), pp. 87-93.

7. Palchykov O.O. Determination of the effective permittivity of a heterogeneous material. Electrical engineering \& electromechanics, 2020, no. 2, pp. 59-63. doi: 10.20998/2074272X.2020.2.09.

8. DSTU 3467-96. Papir kondensatornyj. Zagal'ni tehnichni umovy [State Standard 3467-96. Capacitor paper. General technical conditions]. Kyiv, Derzhstandart Ukraine Publ., 1996. 34 p. (Ukr).

9. Zhang T., Du J., Lei Y., Cheng Y., Liu W., Yi X., Yin J., Yu P. Effect of pores on dielectric breakdown strength of alumina ceramics via surface and volume effects. Journal of the European Ceramic Society, Jul. 2020, vol. 40, no. 8, pp. 30193026, doi: 10.1016/j.jeurceramsoc.2020.03.024.

10. Entsiklopediia polimerov. T.1. Pod red. V. A. Kargina [Encyclopedia of polymers. Vol. 1. Edited by V.A. Kargin]. Moscow, Sov. Ents. Publ., 1972. 1224 p. (Rus).

11. Osipenko V.I., Stupak D.O., Pozdeev S.V. Break-down of liquid by a number of impulses in wire electrodischarge machining. Metal and casting of Ukraine, 2009, no. 11-12, pp. 60-64. (Rus).

Received 29.09.2020

Accepted 16.10.2020

Published 24.12.2020

O.O. Palchykov, Candidate of Technical Science, Admiral Makarov National University of Shipbuilding, 9, Heroyiv Ukraine Ave, Mykolaiv, Ukraine, 54025, e-mail: ole2012hulk@gmail.com

How to cite this article:

Palchykov O.O. Breakdown voltage of micron range air inclusions in capacitor paper. Electrical engineering \& electromechanics, 2020, no. 6, pp. 30-34. doi: 10.20998/2074-272X.2020.6.05. 